\title{
Czy przyimek ogólnorelacyjny w stosunku do jest równoznaczny z jednostkami w odniesieniu do i w porównaniu $z$ ?
}

Słowa klucze: przyimki ogólnorelacyjne, przyimki wtórne, znaczenie przyimka

1. Tematem rozważań, które przedstawię w tym artykule, są właściwości semantyczne przyimkowej jednostki języka ${ }^{1}$ (dalej PJJ) w stosunku do $\mathrm{N}_{\mathrm{G}}$. Znaczenie tego przyimka nie zostało do tej pory zdefiniowane za pomoca jednostek semantycznie prostszych, a w świetle faktu, iż istniejąjuż wymagające weryfikacji charakterystyki semantyczne jednostek wobec (Bera 1997) i względem (Bera 1998), kolejnym krokiem, który należy zrobić w badaniach nad klasą przyimków ogólnorelacyjnych, jest analiza semantyczna PJJ w stosunku do $\mathrm{N}_{\mathrm{G}}$. Niniejszy artykuł stanowi jedynie pierwszy etap pracy nad znaczeniem tej jednostki.

${ }^{1}$ Rozpowszechnione w pracach dotyczących przyimków pojęcie przyimkowej jednostki języka (PJJ) pochodzi z pracy Macieja Grochowskiego (1995: 89). Denotację tego pojęcia stanowią tylko te spośród wyrażeń uznawanych powszechnie za przyimki na podstawie ich postaci graficznej, które funkcjonują w tekstach współczesnego języka polskiego jako jednostki języka (zob. Bogusławski 1976, Bednarek, Grochowski 1993: 13-15). 
2.1. Liczne informacje na temat tego przyimka można znaleźć w pracach, które łączy to, że analiza semantyczna PJJ w stosunku do $\mathrm{N}_{\mathrm{G}}$ nie była ich celem. Są to prace:

a) dotyczące większej liczby przyimków, w tym także $w$ stosunku do $\mathrm{N}_{\mathrm{G}}$ : Grochowski 1976, Kosek 1995, Łapa 2006, Milewska 2003a, 2003b, Żeberek 1994;

b) dotyczące pojedynczych PJJ, semantycznie bliskich przyimkowi $w$ stosunku do $\mathrm{N}_{\mathrm{G}}$ : Bera 1995, 1998;

c) poświęcone jednostkom stanowiącym w wypowiedzeniach języka polskiego inny niż obligatoryjnie prawostronny kontekst przyimka $w$ stosunku do $\mathrm{N}_{\mathrm{G}}$, głównie przymiotnikom: Szupryczyńska 1978, Jędrzejko 1993, Dróżdż-Łuszczyk 2007, 2008;

d) opisujące przeobrażenia systemu składniowego języka polskiego (między innymi proces powstawania przyimków wtórnych i zmiany rekcji wyrazów): Buttler 1976, 1988.

Wyczerpujące omówienie stanu badań, niezależnie od zastosowanej metody prezentacji dotychczasowej wiedzy, musiałoby przekroczyć ramy artykułu, dlatego w tym miejscu ograniczę się do przedstawienia najistotniejszych hipotez, natomiast po inne będę sięgał doraźnie. W chronologicznie pierwszej z wymienionych prac (Grochowski 1976: 91) zostały określone możliwe pozycje składniowe frazy nominalnej przyimkowej, której składnikiem jest w stosunku do. Fraza taka a) nie występuje w pozycji predykatu podstawowego (1); b) może zajmować pozycję argumentu implikowanego semantycznie przez predykat podstawowy (2) lub c) może zajmować pozycję dodanego wyrażenia predykatywnego (3). Por. np.:

(1) *Dziennikarz był w stosunku do widzów.

(2) Kierowca był nieuprzejmy w stosunku do pasażerów.

(3) Silnik jest słaby w stosunku do wielkości auta.

Wykorzystując szkicową eksplikację semantyczną zaproponowaną przez E. Jędrzejko dla klasy przymiotników nazywających zachowania ludzi wobec innych ludzi (m.in. bezlitosny, hojny, mity, nieuprzejmy, okrutny, opryskliwy, uprzejmy, wyrozumiały, życzliwy): 'x działa ze skutkiem zl i y doznaje owego zl i samo działanie z lub jego skutek jest dobre lub złe dla y' (Jędrzejko 1993: 91), można stwierdzić, że w strukturze semantycznej przymiotników należących do tej klasy znajdują się komponenty, których sensy wymagają uzupeł- 
nienia nazwą osobową. Frazy nominalne z przyimkiem $w$ stosunku do należy więc bez wątpienia uznać za implikowane semantycznie przez tę klasę predykatów, co jest potwierdzeniem wspomnianej hipotezy M. Grochowskiego. Nasuwa się tu pytanie, czy przyimek $w$ stosunku do w takiej pozycji ma znaczenie. W literaturze przedmiotu cały czas dyskutowane jest zagadnienie, w jakich pozycjach składniowych przyimek pełni funkcję semantyczną, a w jakich nie przysługuje mu znaczenie (zob. Karolak 1999: 472-475, Przybylska 2002: 55-59, Nowak 2006: 27-30, 2008: 97-100). S. Karolak uznaje, że przyimki w tej pozycji pełnią funkcję operatorów powierzchniowosyntaktycznych (1999: 473); R. Przybylska (2002: 56-57) przyjmuje, że przyimek zawsze pełni jakąś funkcję semantyczną, co nie jest równoznaczne ze stwierdzeniem, że zawsze jest PJJ; T. Nowak zaś uważa, że przyimkowi nie przysługuje funkcja semantyczna tylko wtedy, gdy jest on częścią frazy implikowanej semantycznie i formalnie przez predykat podstawowy (Nowak 2008: 98) ${ }^{2}$. Uważam, że współzajmowanie (wraz z rzeczownikiem) przez przyimek $w$ stosunku do pozycji implikowanej semantycznie nie stanowi wystarczającej podstawy, aby uznać, że w tym typie kontekstów jest on pozbawiony znaczenia. Wrócę do tej kwestii w dalszej części artykułu.

W kwestii statusu leksykalnego przyimka $w$ stosunku do przy nadrzędnikach należących do wyżej wspomnianej klasy przymiotników wypowiedziała się M. Bera (1998: 6), uznając, iż w stosunku do, występując zamiennie z przyimkami wobec i względem, jest częścią większych, przymiotnikowych jednostek języka. Głównym argumentem badaczki przemawiającym za takim rozstrzygnięciem był fakt, iż fraza przyimkowa jest semantycznie implikowana przez przymiotnik, jednak z faktu, iż dany przyimek w określonym typie użyć zajmuje pozycję argumentu PWPA nie wynika to, że przyimek ten stanowi wraz z wyrażeniem predykatywnym większą, nieprzyimkową jednostkęjęzyka. Np. predykaty zawierające w strukturze semantycznej składnik 'znajdować się' lub nazywające pozycję przestrzenną przedmiotu implikują semantycznie frazy przyimkowe lokatywne (M. Grochowski: 1984: 256), z czego nie wynika, iż w zdaniach:

(4) Akordeon leżał na podłodze.

(5) Nocna lampka stoi w garażu.

2 Stanowisko T. Nowaka dotyczy tylko lokatywnych fraz przyimkowo-nominalnych. 
występują jednostki cośl leży na czymś2 i coś1 stoi w czymś2. Kwestia statusu leksykalnego przyimka $w$ stosunku do w poszczególnych typach użyć pozostaje zatem nierozwiązana.

Trzecią istotną hipotezą postawioną w literaturze przedmiotu w odniesieniu do przyimka $w$ stosunku do jest stwierdzenie I. Kosek (1995), iż istnieją dwie homonimiczne jednostki o postaci $w$ stosunku do. Pierwsza $\mathrm{z}$ nich może być używana zamiennie $\mathrm{z}$ wobec, druga $-\mathrm{z} w$ porównaniu $z$. Podstawą wyróżnienia dwóch równokształtnych jednostek były dla badaczki dwa testy. Jeden z nich miał zdać sprawę z możliwości / niemożliwości zastąpienia pierwszego lub ostatniego członu przyimka $w$ stosunku do innym przyimkiem. Według badaczki możliwość taką stwarza przyimek $w$ stosunku do w użyciu porównawczym. Zdania: *Pensje nauczycielskie byty niskie na stosunku do ciagle rosnacych cen, *Pensje nauczycielskie byty niskie w stosun$\boldsymbol{k} \boldsymbol{u} \boldsymbol{z}$ ciagle rosnacymi cenami pozwalają jednak twierdzić, że tak nie jest. Drugim argumentem badaczki na rzecz wyróżnienia dwóch jednostek $w$ stosunku do jest fakt, iż w języku niemieckim przyimkowi $w$ stosunku do w zależności od typu użycia odpowiada jednostka gegenüber lub im Verhältnis $z u$. Przyjmując za M. Grochowskim (1982: 80), iż wyróżnianie par jednostek homonimicznych jest z punktu widzenia semantyki synchronicznej jednym z dwóch sposobów opisu niejednoznaczności leksykalnych jednostek języka, wychodzę z założenia, iż istnieje jedna jednoznaczna PJJ $w$ stosunku do $\mathrm{N}_{\mathrm{G}}$. Uważam, że dopóki nie podejmie się próby stworzenia jednej charakterystyki semantycznej PJJ $w$ stosunku do $\mathrm{N}_{\mathrm{G}}$, nie będzie dostatecznych podstaw, aby mówić o dwóch jej znaczeniach. Łatwo dostrzegalny fakt, iż ten sam przyimek może być wykładnikiem kilku różnych relacji, i w związku z tym w różnych użyciach może być substytuowany za pomocą różnych zbiorów semantycznie pokrewnych przyimków, nie powinien prowadzić do przypisywania mu wielu znaczeń.

2.2. Poza wymienionymi pracami źródło wiedzy o znaczeniu i łączliwości przyimka $w$ stosunku do stanowią ogólne i frazeologiczne słowniki współczesnego języka polskiego. W żadnym ze znanych mi słowników przyimek $w$ stosunku do nie został scharakteryzowany jako monosemiczny ${ }^{3}$. SJPD po-

3 W pracach z zakresu semantyki leksykalnej bardzo często punktem wyjścia jest krytyka tzw. definicji synonimicznych, nierzadko kończących się zapowiadającym re- 
daje, że $w$ stosunku do ma dwa tzw. odcienie znaczeniowe. Charakterystyka semantyczna pierwszego z nich składa się z przyimków $w$ porównaniu $z$ i $w$ zestawieniu $z$, natomiast za synonim drugiej uznano $w$ odniesieniu do. W SJPSz, choć nie explicite, wyróżnia się dwie równokształtne jednostki $w$ stosunku do, o czym świadczy fakt, iż tylko jedna z nich została opatrzona kwalifikatorem fraz. W obu tych słownikach uznano, że $w$ stosunku do (niezależnie od znaczenia, w którym występuje) łączy się z rzeczownikami osobowymi i nieosobowymi. Charakterystyka semantyczna zaproponowana w SJPD została podtrzymana w SJPSz, SWJP i w USJP, z tą różnicą, że w SWJP tę z dwóch definicji, która w SJPD i SJPSz składała się tylko z wyrażenia $w$ odniesieniu do, rozszerzono o człony wobec i względem.

Zupełnie inaczej został scharakteryzowany omawiany przyimek w ISJP, w którym wyróżniono dwa przysłówki o postaci $w$ stosunku i przyimek w stosunku do:

'4.1 Jeśli rozpatrujemy ilość, wielkość, charakter lub położenie jakiejś rzeczy w stosunku do innej rzeczy, to w ocenie lub opisie tej pierwszej bierzemy pod uwagę tę drugą;

'4.2 Nasze działania, postawy, zobowiązania itp. w stosunku do kogoś lub czegoś określają związek, jaki łączy nas z tą osobą lub rzeczą';

'4.3 Jeśli jakiejś nazwy używamy w stosunku do kogoś lub czegoś, to tę osobę lub rzecz nazywamy w taki sposób'.

Rozwiązanie zaproponowane w tym słowniku z kilku powodów budzi wątpliwości. Ostatni segment przyimka $w$ stosunku do, niezależnie od sposobu jego użycia, nie podlega redukcji ani substytucji:

(6) Pomoc ta była małym okruchem w stosunku do potrzeb.

(7) *Pomoc ta była małym okruchem w stosunku.

w związku z czym należy uznać, iż nie istnieje przysłówek $w$ stosunku. Warto też zauważyć, że drugi z wyróżnionych przysłówków uznano za równoznaczny z przysłówkiem $w$ odniesieniu, a takiego przysłówka w słowniku nie zarejestrowano - zarejestrowano przyimek w odniesieniu do.

gres nieskończony ,itd.” Uznaję, iż zagadnienie niedostatków tej metody opisu znaczeń jest znane i w związku z tym nie ma potrzeby go tu omawiać. 
Jeszcze inne rozwiązanie proponuje WSFJP, w którym odnotowano dwie jednostki, wyróżnione na podstawie odmiennych ograniczeń semantycznych nakładanych na rządzony rzeczownik. Jednostce $w$ stosunku do czegoś przypisuje się dwa znaczenia. Charakterystykę semantyczną pierwszego tworzą przyimki w odniesieniu do czegoś i wobec czegoś, natomiast drugiego - wyrażenie porównujac coś. Druga z wyróżnionych jednostek ma postać w stosunku do kogoś. Uznano ją za synonimiczną z wobec kogoś i w odniesieniu do kogoś. Kwestię zasadności wyróżniania dwóch jednostek o postaci $w$ stosunku do na podstawie ich łączliwości z rzeczownikiem poruszę w dalszej części tekstu.

3.1. Najważniejszym celem niniejszego artykułu jest uzasadnienie hipotezy, iż trzy tytułowe PJJ nie są równoznaczne, oraz sformułowanie wniosków dotyczących znaczenia PJJ $w$ stosunku do (na podstawie porównania właściwości semantycznych par PJJ: $w$ stosunku do vs. $w$ odniesieniu do i $w$ stosunku do vs. $w$ porównaniu z), które w przyszłości będą mogły być wykorzystane do budowy definicji znaczenia tej jednostki. Przyjmuję tu postulaty sformułowane w odniesieniu do badań nad PJJ przez M. Grochowskiego (1995). Przede wszystkim należy ustalić, w jakich kontekstach wyrażenie o postaci $w$ stosunku do jest PJJ, w jakich stanowi część większych, nieprzyimkowych jednostek języka, podlegających jako całości leksykalne odrębnej charakterystyce semantycznej, w jakich natomiast jest konstrukcja syntaktyczną. W tym celu przedstawię zbiór przykładowych wypowiedzeń, w których występuje wyrażenie $w$ stosunku do. Ze względu na fakt, iż przyimek ten występuje w tekstach współczesnego języka polskiego w kontekstach bardzo różnorodnych, zebrane poniżej wypowiedzenia z pewnością nie stanowią pełnej reprezentacji typów jego użyć (nie ilustrują wszystkich możliwych typów relacji tworzonych z mniejszym lub większym udziałem tego przyimka), niemniej jednak wydaje się, że zbiór ten jest wystarczająco zróżnicowany, aby ustalić znaczenie inwariantne PJJ $w$ stosunku do $\mathrm{N}_{\mathrm{G}}$, umożliwiające jej funkcjonowanie w wypowiedzeniach komunikujących liczne relacje temporalne, lokatywne, logiczne i inne, którym trudno jest przyporządkować podobną etykietkę.

(8) W raporcie zwraca się uwagę na istotne różnice w stosunku do osób pochodzenia żydowskiego w różnych krajach Unii. 
(9) I to przede wszystkim wydaje się zasadniczym novum w stosunku do dotychczasowej twórczości artysty.

(10) Był bowiem Broniewski artystą bardzo świadomym, powiedziałbym - wyrafinowanym, gdyby ten przymiotnik nie wydawał się dziwny w stosunku do niego.

(11) Padały ostre słowa w stosunku do poprzednich władz.

(12) Jesteś w stosunku do niego uprzedzony.

(13) Dawid żywił w stosunku do powstańców uczucie niechęci.

(14) Organista był ordynarny w stosunku do młodej pary.

(15) Magda jest raczej nieufna w stosunku do obcych.

(16) Mężczyzna był agresywny w stosunku do policjantów.

(17) Czym tłumaczyłby pan tak daleko posuniętą szczerość Stroopa w stosunku do pana?

(18) Mimo ogólnie przyjaznej osobowości, Krzysztof wykazuje wrogość w stosunku do doktor Kowalskiej.

(19) Tematyka naszych spotkań będzie komplementarna w stosunku do wykładu.

(20) Leki naturalne przedstawiono jako alternatywne w stosunku do antybiotyków.

(21) Budynek szpitalny stał nieco na ukos w stosunku do ulicy.

(22) Zauważa się jedynie jej głowę, zbyt dużą w stosunku do wątłego korpusu.

(23) Złoty wczoraj zyskał na wartości w stosunku do dolara i euro.

(24) Struna E brzmi trochę za wysoko w stosunku do struny A.

(25) Przy ruszaniu pod górę, zbyt późne zwolnienie pedału sprzęgła w stosunku do zwolnienia hamulca może spowodować stoczenie się pojazdu.

Wyrażenie $w$ stosunku do występujące w wypowiedzeniu (8) nie jest PJJ. Jego pierwszy segment jest częścią odrębnej jednostki o postaci różnice $w$ czymś, natomiast dwa pozostałe segmenty: stosunku do reprezentują jedną $\mathrm{z}$ jednostek fundowanych na rzeczowniku stosunek ${ }^{4}$. O tym, iż nie mamy tu

${ }^{4}$ Por. poczynioną mimochodem uwage J. Puzyniny (2000: 18): „Stosunek do kogoś, czegoś (leksem niesamodzielny!) ma najogólniejsze znaczenie [...]”; zob. też Kosek (1995: 261): „Rzeczownik STOSUNEK wymaga wystąpienia w tekście przyimka DO”. Istnieje kilka jednostek rzeczownikowych z komponentem stosunek. Nie wszystkie takie jednostki są zbudowane w ten sam sposób, z czego nie zdają sprawy słowniki. Oprócz jednostki stosunek do $\mathrm{N}_{\mathrm{G}}$ istnieje też jednostka zarejestrowana przez A. Bogusławskiego 
do czynienia z PJJ $w$ stosunku do $\mathrm{N}_{\mathrm{G}}$, świadczy fakt, iż słowo stosunek daje się zastąpić jednostkami semantycznie pokrewnymi:

(8') W raporcie zwraca się uwagę na istotne różnice $\mathbf{w}$ nastawieniu do osób pochodzenia żydowskiego w różnych krajach Unii.

W pozostałych kontekstach przyimek $w$ stosunku do $\mathrm{N}_{\mathrm{G}}$ nie dopuszcza zmiany tego komponentu:

(14') *Organista był ordynarny w nastawieniu do młodej pary.

Występujące w przykładzie (9) wyrażenie novum w stosunku do jestem skłonny uznać za czterosegmentową jednostkę języka. Nie dopuszcza ona wymiany komponentu przyimkowego nawet na semantycznie pokrewne wobec i względem.

W wypowiedzeniach (10)-(11) przyimek $w$ stosunku do został użyty w kontekście typowym dla $w$ odniesieniu do. Nie są to jednostki równoznaczne, choć występują zamiennie w części kontekstów. Różnice między nimi omówię w punkcie 3.2.

W wypowiedzeniach (12) i (13) segment do, stanowiący część jednostek uprzedzony do kogoś / czegoś i ktośl żywi coś (klasa nazw uczuć) do kogoś2 / czegoś, przyimek do został zastąpiony przyimkiem $w$ stosunku do. Świadczą o tym duże różnice $\mathrm{w}$ częstotliwości użycia form $\mathrm{z}$ do i $\mathrm{z} w$ stosunku $d o^{5}$. Nie zawsze jednak można ustalić, czy któryś z alternujących przyimków jest dla danego nadrzędnika podstawowy. Interpretacja konstrukcji nadrzędnik $+w$ stosunku do jest szczególnie kłopotliwa wtedy, gdy przyimek ten zaczyna występować przy danym nadrzędniku w sposób równoprawny

\footnotetext{
i J. Wawrzyńczyka (1993) pod postacią: stosunek ktoś ${ }_{i} /$ coś $_{i}-$ ktoś $_{j} /$ coś $_{j}$. Przyimek do nie jest też częścią jednostki, która została użyta w zdāniu: Podczas orgii ódbyt stosunek $z$ dwiema młodymi blondynkami. Prawdopodobnie istnieje też jednostka o postaci stosunek między $\mathrm{N}_{1} i \mathrm{~N}_{2}$. Poprawne wyodrębnienie jednostek rzeczownikowych z komponentem stosunek pozwoliłoby zmniejszyć liczbę znaczeń przypisywanych w słownikach jednostce stosunek, jednak jest to odrębne, skomplikowane zadanie badawcze. Należałoby również rozważyć kwestię włączenia jednostki stosunek w jednym z jej znaczeń do zbioru jednostek semantycznie prostych (zob. na ten temat Apresjan 1971: 329).

5 Dane, które przedstawiam, pochodzą z Narodowego Korpusu Języka Polskiego [1.10.2010]. Wyrażenie uprzedzony do występuje w nim 154 razy, uprzedzony $w$ stosun$k u$ do - 2 razy. Wyrażenie żywi do pojawia się w NKJP 85 razy, zaś żywi w stosunku do - raz.
} 
z utrwalonym zwyczajowo przyimkiem pierwotnym, przy czym znaczenie całej konstrukcji jest identyczne: analogiczny do / analogiczny z / analogiczny w stosunku do; bliskoznaczny z / bliskoznaczny w stosunku do; opozycyjny do / opozycyjny w stosunku do; przeciwstawny do / przeciwstawny w stosunku do. Zjawisko „zastępowania” lub tylko „wzmacniania” tradycyjnie używanych w danym kontekście przyimków prostych dostrzegła D. Buttler (1988: 74): „Niewiele również neologizmów przyimkowych wchodzi do użycia. Należą do nich wyrażenia analityczne zastępujące lub tylko wzmacniające wielofunkcyjny przyimek prosty, tradycyjnie używany w tym kontekście, np. w zamian + gen. zamiast za [...], w stosunku do [podkr. moje: S.W.] zamiast do lub ogólnorelacyjnego od [...] czy rzadkie, ale ekspansywne odnośnie do czego w funkcji do [...]".

Użyte w wypowiedzeniach (14)-(16) przymiotniki należą do podklasy przymiotników oceniających, nazywających zachowania ludzi wobec innych ludzi (zob. Szupryczyńska 1978: 93-94, Jędrzejko 1993). Przymiotniki z tej klasy stanowią typowy kontekst nadrzędnikowy przyimka $w$ stosunku do, który jest w takiej pozycji regularnie wymienny na wobec i względem, a czasami także na dla, przy czym zmiana przyimka nie pociąga za sobą zmiany znaczenia wypowiedzenia (Bera 1995: 10). Przemawia to za uznaniem przyimka $w$ stosunku do w tym typie kontekstów za części jednostek przymiotnikowych, jednak mogłaby to być decyzja pochopna. Równoznaczność wypowiedzeń różniących się tylko przyimkiem nie musi oznaczać, że przyimki, których można w ten sposób użyć, są synonimiczne. Nie powinno też prowadzić do wniosku, że są semantycznie puste. Różnice między znaczeniami poszczególnych przyimków ogólnorelacyjnych są bardzo subtelne, a przy tym dotąd nierozpoznane. Istnieje zatem duże prawdopodobieństwo, że to właśnie typ opozycji semantycznych pozwala im wymiennie występować w pewnych kontekstach bez zmiany znaczenia wypowiedzenia. Przedstawiony pogląd może się wydawać dość kontrowersyjny, dlatego wymaga uzasadnienia. Zjawiskiem dobrze znanym jest możliwość wyrażania za pomocą różnych przyimków tej samej relacji. Np. zdania (26) i (26’) są równoznaczne, choć przyimki z i przeciw z pewnością nie są nawet bliskoznacznikami ${ }^{6}$.

(26) Polacy w meczu półfinałowym zagrają z Niemcami.

(26’) Polacy w meczu półfinałowym zagrają przeciw Niemcom.

${ }^{6}$ Odmienne zdanie na ten temat wyraził E. Grodziński (1985: 215). 
Przyimki te mogą występować zamiennie tylko przy nadrzędnikach komunikujących wzajemne przeciwdziałanie członów relacji, takich jak: batalia, bój, mecz, partia, walka, wojna (ale nie współdziałanie: flirtuje z i *flirtuje przeciw). Przyimki w pozycji implikowanej semantycznie nie są głównym środkiem relacjotwórczym, lecz jedynie pełnią funkcję pomocniczą wobec nadrzędnika, który determinuje charakter relacji - ilość i jakość jej członów. Wymienione przed chwilą rzeczowniki komunikują jednoczesne działanie dwóch osób (lub grup osób), dlatego mogą łączyć się z frazą nominalną otwieraną przez $z$. Komunikują również to, że obie strony chcą spowodować, aby strona przeciwna nie mogła zrobić tego, co chce zrobić, stąd łączliwość $\mathrm{z}$ przeciw. Wracając do przyimka $w$ stosunku do, trzeba więc zauważyć, że elementem wyrażeń typu: uległy $w$ stosunku do, wulgarny $w$ stosunku do, złośliwy w stosunku do, wyznaczającym semantyczną klasę rzeczowników, które mogą zajmować pozycję przeznaczoną dla adresata czynności, jest nie przyimek, lecz przymiotnik (ściślej - jego komponenty treściowe). Hipotezę tę potwierdza kilka faktów:

a) Tylko nieliczne przymiotniki mają zdolność wyrażania relacji zwrotnej, na co żadnego wpływu nie ma przyimek:

(27) Nie bądź w stosunku do niego taka krytyczna.

(27’) Nie bądź w stosunku do siebie taka krytyczna.

(28) Byłeś w stosunku do Ewy bezczelny! (28') *Byłeś w stosunku do siebie bezczelny!

b) Niektóre przymiotniki należące do omawianej grupy komunikują zachowania, które wtórnie mogą być odnoszone do zwierząt lub przedmiotów:

(29) Kto jest okrutny w stosunku do zwierząt, ten nie może być dobrym człowiekiem.

$\left(29^{\prime}\right)$ *Kto jest uszczypliwy w stosunku do zwierząt, ten nie może być dobrym człowiekiem.

(30) Byłeś niesprawiedliwy w stosunku do tego projektu.

(30’) *Byłeś nielojalny w stosunku do tego projektu.

Dewiacja semantyczna przykładów (29’) i (30’) nie jest spowodowana wykluczaniem się znaczeń przyimka i postpozycyjnego rzeczownika, lecz niespełnieniem przez rzeczownik indywidualnych wymagań semantycznych przymiotnika. Zaobserwowana tu cecha przyimka $w$ stosunku do jest istot- 
na z punktu widzenia prowadzonych rozważań, ponieważ pozwala odrzucić konieczność wyróżniania dwóch jednostek $w$ stosunku do na podstawie różnych ograniczeń semantycznych nakładanych na pozycję zajmowaną przez rzeczownik, jak to ma miejsce w WSFJP.

Przyjmuję, że w wypowiedzeniach (14)-(25) występuje odrębna PJJ w stosunku do $\mathrm{N}_{\mathrm{G}} \mathrm{i}$ że to właśnie pokrewieństwo semantyczne przyimków wobec, względem i w stosunku do sprawia, iż jednostki te występują w tych samych typach kontekstów. D. Buttler (1976: 209) uważa nawet, że są to jednostki synonimiczne, jednak nie ma pewności, czy przez synonimię rozumie badaczka relację równoznaczności, bliskoznaczności, czy obie te relacje (z ewentualnym uprzywilejowaniem jednej z nich).

3.2. Różnica między PJJ w odniesieniu do i w stosunku do polega na tym, że pierwsza $\mathrm{z}$ nich występuje $\mathrm{w}$ wypowiedzeniach, w których jest mowa o używaniu języka, a dokładniej - w których stwierdza się (31) lub komentuje (32) używanie pewnych wyrażeń.

(31) Miano „sztuki brutalnej” stosował też w odniesieniu do własnego malarstwa.

(32) Metafora kija i marchewki wydaje się zbyt sielankowa w odniesieniu do polityki Karola Wielkiego wobec tej grupy.

W wypowiedzeniach z tym przyimkiem bardzo często występują nazwy w supozycji materialnej, sygnalizowanej cudzysłowem lub za pomocą słów nazwa, określenie, pojęcie, termin itp. Zdania takie mają więc charakter metajęzykowy - nadawca komunikuje za ich pomocą swoje spostrzeżenia, postulaty, wątpliwości dotyczące używania pewnych wyrażeń, gdy tematem jest obiekt, do którego odsyła rzeczownik stanowiący w wypowiedzeniu komentującym kontekst prawostronny PJJ $w$ odniesieniu do $\mathrm{N}_{\mathrm{G}}$. Jednostka ta nie nakłada na rzeczownik żadnych ograniczeń semantycznych, ponieważ skoro można mówić o wszystkim, to można też dostrzegać i komentować mówienie o wszystkim. Bardzo ważny dla rozważań nad znaczeniem tej PJJ jest jej stosunek do struktury tematyczno-rematycznej wypowiedzeń. Nie jest ona tematyzatorem ${ }^{7}$. Również stwierdzenie, że wskazuje wyrażenia po-

7 Terminu tematyzator używam tu w znaczeniu, jakie nadał mu M. Grochowski (1985). 
tencjalnie tematyczne, czyli nadające się na temat innych wypowiedzeń, byłoby fałszywe. Skoro tematem może być wszystko i osoby posługujące się językiem polskim wciąż tę możliwość wykorzystują (abstrahuję tu od zjawiska tabuizacji pewnych dziedzin życia), to w systemie leksykalnym nie są potrzebne elementy o treści: 'o tym można mówić'. PJJ $w$ odniesieniu do $\mathrm{N}_{\mathrm{G}}$, a ściślej, jej swobodna łączliwość z rzeczownikiem, tylko mimochodem potwierdza fakt, że mówić można o wszystkim. Funkcja tego przyimka jest inna i sprowadza się do wskazania, że w komentowanym użyciu języka była mowa o tym, czego nazwą jest postpozycyjny względem $w$ odniesieniu do rzeczownik. Potwierdzeniem tej hipotezy jest fakt, że część zdania, pozostała po usunięciu z niego frazy przyimkowej, mówi o użyciu języka, które musiało / musi / musiałoby mieć temat. Intencją nadawcy jest wskazanie tego tematu, gdyż wie on, że jeśli nie użyje frazy z tym przyimkiem, wypowie sąd niepełny, zakomunikuje coś innego niż to, co chce powiedzieć, niż to, co jest przedmiotem jego myśli:

(33) Nie rozumiem, jak można używać słowa wolność w odniesieniu do jakiejkolwiek społeczności?

(33’) Nie rozumiem, jak można używać słowa wolność?

Ażeby dobrze, bez przypadkowych zniekształceń oddać swoją myśl, nadawca powyższego zdania informuje, czego dotyczy użycie języka, które właśnie komentuje. Natura mowy, będącej przedmiotem procesów mentalnych nadawcy, wymusza na nim zakomunikowanie tego, co było ${ }^{8}$ przedmiotem wypowiedzi, o której chce mówić. W tym celu, posługując się PJJ w odniesieniu do $\mathrm{N}_{\mathrm{G}}$ wprowadza do wypowiedzenia istotny składnik swojej myśli. Na tej podstawie można powiedzieć, że jednostka ta informuje o tym, w jaki sposób mówiący postrzega to, o czym mówi. W dużej mierze analogiczne właściwości semantyczne ma przyimek $w$ stosunku do $\mathrm{N}_{\mathrm{G}}$. Używając go, również informuje się o określonym sposobie postrzegania rzeczywistości, mianowicie o tym, że desygnat rzeczownika stanowiącego kontekst prawostronny tego przyimka jest nieodłączną częścią wycinka rzeczywistości, który

8 Wypowiedzenia zawierające PJJ $w$ odniesieniu do $\mathrm{N}_{\mathrm{G}}$ najczęściej komentują wcześniejsze użycia języka, choć chcę podkreślić, że rodzaj relacji czasowej między komentowanym użyciem języka a wypowiedzeniem, w którym znajduje się w odniesieniu do, jest z punktu widzenia znaczenia tego przyimka nierelewantny. 
percypujemy. Ta część znaczenia obu omawianych PJJ jest inwariantna dla przyimków ogólnorelacyjnych, w związku z czym, odpowiednio sformułowana, powinna się znaleźć w definicjach wszystkich PJJ tworzących tę klasę. Różnica semantyczna między $w$ odniesieniu do $\mathrm{N}_{\mathrm{G}} \mathrm{i} w$ stosunku do $\mathrm{N}_{\mathrm{G}}$ polega na tym, że są one wyspecjalizowane w komunikowaniu określonego postrzegania relacji zachodzących między obiektami należącymi do różnych kategorii ontologicznych. Pierwsza komunikuje postrzeganie relacji zachodzącej między użyciem języka a dowolnym wycinkiem rzeczywistości, druga komentuje sposób postrzegania relacji między osobą a osobą, między obiektem a obiektem, a wtórnie, metaforycznie i metonimicznie także innych relacji. W stosunku do $\mathrm{N}_{\mathrm{G}}$ nie mówi, co jest istotą owych relacji. Tę funkcję pełnią podstawowe wyrażenia predykatywne. PJJ $w$ stosunku do $\mathrm{N}_{\mathrm{G}}$ jest mniej restrykcyjne, jeśli chodzi o rodzaj obiektów, które są członami komentowanej relacji. Różnice te mają swoje odzwierciedlenie w tekstach współczesnego języka polskiego. Trzeba jednak brać pod uwagę pewne komplikacje, jak choćby tę, że relacja międzyludzka, polegająca na kierowaniu słów do kogoś, kto jednocześnie jest tematem wypowiedzi, może być ujmowana zarówno za pomocą $w$ odniesieniu do $\mathrm{N}_{\mathrm{G}}$, jak i $w$ stosunku do $\mathrm{N}_{\mathrm{G}}$. Dlatego też $\mathrm{w}$ wypowiedzeniach (34) i (35), które komunikują o mówieniu, możliwe jest użycie obu tych przyimków, natomiast w wypowiedzeniu (36), w którym relacja międzyludzka nie polega na mówieniu, w związku z czym nadawca nie musi wskazywać tematu (nieaktualnego!), może wystąpić tylko $w$ stosunku do $\mathrm{N}_{\mathrm{G}}$ :

(34) Nigdy nie pojawił się taki zarzut w stosunku do Nowaka.

(34') Nigdy nie pojawił się taki zarzut w odniesieniu do Nowaka.

(35) Ktokolwiek śmiał wyrazić krytykę w stosunku do sowieckich doradców, był wysyłany do Rosji, gdzie odpowiednio się z nim rozprawiano.

(35') Ktokolwiek śmiał wyrazić krytykę w odniesieniu do sowieckich doradców, był wysyłany do Rosji, gdzie odpowiednio się z nim rozprawiano.

(36) Represje w stosunku do harcerzy i mnie trwały dalej.

(36') *Represje w odniesieniu do harcerzy i mnie trwały dalej.

Ta przyczynkowa refleksja nad znaczeniem PJJ $w$ odniesieniu do $\mathrm{N}_{\mathrm{G}}$ nie może zastąpić gruntownej analizy semantycznej ani też nie stwarza podstaw do podjęcia próby zdefiniowania tej interesującej jednostki. Można jednak 
pokusić się o stwierdzenie, że komponentem jej znaczenia, odróżniającym ją od pozostałych przyimków ogólnorelacyjnych, jest 'kiedy mówi- o'9.

3.3. Źródła różnic semantycznych między przyimkami $w$ stosunku do i $w$ porównaniu $z$ należy szukać $\mathrm{w}$ znaczeniach rzeczowników stosunek i porównanie. Z rozważań Leibniza nad pojęciami porównania i stosunku dowiadujemy się, że: „stosunek to coś innego niż porównanie. Stosunki bowiem są albo stosunkami porównania, albo zbieżności. Pierwsze dotyczą zgodności lub niezgodności [...], która obejmuje podobieństwo, równość, nierówność etc. Drugie zawieraja jakiś zwiazek, jak przyczyny i skutku, całości i części, położenia i szeregu, etc.” (Leibniz 1955: 149). Istotną cechą semantyczną odróżniającą $w$ stosunku do $\mathrm{N}_{\mathrm{G}}$ od $w$ porównaniu $z$ jest informowanie przez $w$ stosunku do o tym, że człony relacji pozostają w jakimś (sprecyzowanym predykatem) związku w rzeczywistości, który nie polega jedynie na współistnieniu, wobec czego są postrzegane łącznie i nadawca nie ma możliwości dowolnego dobierania członów tego związku. PJJ w porównaniu z komentuje relacje, o których kształcie decyduje sam nadawca. Jedynym warunkiem koniecznym do przeprowadzenia porównania jest posiadanie przez obiekty mu podlegające wspólnej cechy. PJJ $w$ stosunku do nie daje nadawcy takiej swobody. Jednak, tak jak w przypadku wcześniej zestawionej pary PJJ, w części kontekstów $w$ stosunku do i $w$ porównaniu $z$ mogą występować wymiennie, co jest konsekwencją faktu, iż obiekty stanowiące człony relacji komentowanej przez nadawcę za pomocą $w$ stosunku do, oprócz tego, że stanowią pewną całość spostrzeżeniową (ze względu na fakt powiązania jakimś typem związku), mogą być do siebie podobne:

(37) Większość wyrobów staniała w stosunku do roku ubiegłego.

(37') Większość wyrobów staniała w porównaniu z rokiem ubiegłym.

(38) Odwrócił się na plecy i sprawdził położenie słońca w stosunku do okolicznych szczytów.

(38’) *Odwrócił się na plecy i sprawdził położenie słońca w porównaniu z okolicznymi szczytami.

9 Fleksja czasownika mówić będzie uzależniona od fleksji czasownika występującego w zdaniu z definiowanym przyimkiem, np.: (31) Miano „,sztuki brutalnej” stosowat też, kiedy mówił o własnym malarstwie. 
4. Zamykając pierwszy etap analizy semantycznej PJJ w stosunku do, należy stwierdzić, że:

a) PJJ $w$ stosunku do nie jest synonimiczna $\mathrm{z}$ jednostkami $w$ odniesieniu do i $w$ porównaniu $z$.

b) W przeciwieństwie do $w$ odniesieniu do nie precyzuje typu współkonstytuowanej relacji, natomiast $\mathrm{w}$ odróżnieniu od $w$ porównaniu $z$ służy do komunikowania, iż obiekty tworzące relację są postrzegane jako całość, a nie zestawiane w celu powiedzenia czegoś o jednym $\mathrm{z}$ nich.

c) Definicja PJJ $w$ stosunku do $\mathrm{N}_{\mathrm{G}}$ powinna przede wszystkim zdawać sprawę $\mathrm{z}$ faktu, iż nadawca, myśląc o relacji nazywanej przez predykat podstawowy, myśli między innymi o tym, do czego odsyła stojący w postpozycji względem przyimka rzeczownik.

\section{Bibliografia}

APRESJAN J., 1971, Koncepcje i metody wspótczesnej lingwistyki strukturalnej. (Zarys problematyki), Warszawa: Państwowy Instytut Wydawniczy.

Bednarek A., Grochowski M., 1993, Zadania z semantyki językoznawczej, Toruń: Wydawnictwo Uniwersytetu Mikołaja Kopernika.

Bera M., 1995, O funkcjach przyimka wobec w strukturze zdania, Poradnik Jezzykowy 5-6, s. 7-11.

Bera M., 1997, Wobec - przyimek wielo- czy jednoznaczny?, AUNC. Filologia Polska XLVIII, s. 35-41.

Bera M., 1998, Propozycja eksplikacji semantycznej przyimka względem, AUNC. Filologia Polska L, s. 5-11.

BogusŁawski A., 1976, O zasadach rejestracji jednostek języka, Poradnik Językowy 8, s. 356-364.

BogusŁawski A., Wawrzyńczyk J., 1993, Polszczyzna, jakq znamy. Nowa sonda słownikowa, Warszawa: Uniwersytet Warszawki, Katedra Lingwistyki Formalnej.

ButTler D., 1976, Innowacje składniowe wspótczesnej polszczyzny. (Walencja wyrazów), Warszawa: Państwowe Wydawnictwo Naukowe.

ButtLen D., 1988, Właściwości syntaktyczne polszczyzny drugiej połowy wieku XIX (schematy zdań i konstrukcji przyimkowych), Prace Filologiczne XXXIV, s. $69-81$.

DróżDż-ŁuszczyK K., 2007, Zero tolerancji dla pewnych użyć tolerancji. O zachodzących współcześnie przemianach w znaczeniach wyrazów tolerować, tolerancja, tolerancyjny, Polonica XXVIII, s. 49-58. 
DróżDż-Łuszczyk K., 2008, Świat ukryty w znaczeniu i znaczenie nieujawnione w słowniku. O przymiotniku obojętny, Prace Filologiczne LIV, s. 79-88.

Grochowski M., 1976, Przyimek jako wykładnik relacji semantycznych między wyrażeniami predykatywnymi, Polonica II, s. 73-91.

Grochowski M., 1982, Zarys leksykologii i leksykografii. Zagadnienia synchroniczne, Toruń: Wydawnictwo Uniwersytetu Mikołaja Kopernika.

Grochowski M., 1984, Składnia wyrażeń polipredykatywnych, w: Z. Topolińska (red.), Gramatyka współczesnego języka polskiego. Składnia, Warszawa: Państwowe Wydawnictwo Naukowe, s. 213-299.

Grochowski M., 1985, Jednostki leksykalne w funkcji tematyzatorów zdań, AUNC. Filologia Polska XXVII, s. 27-38.

Grochowski M., 1995, O możliwościach słownikowej charakterystyki semantycznej przyimkowych jednostek języka, w: M. Grochowski (red.), Wyrażenia funkcyjne w systemie $i$ tekście, Toruń: Wydawnictwo Uniwersytetu Mikołaja Kopernika, s. 84-97.

Grodziński E., 1985, Językoznawcy i logicy o synonimach i synonimii. Studium z pogranicza dwóch nauk, Wrocław: Zakład Narodowy im. Ossolińskich.

ISJP - Bańko M. (red.), 2000, Inny słownik języka polskiego, Warszawa: Wydawnictwo Naukowe PWN.

JĘDRZEJKo E., 1993, Semantyczne właściwości przymiotników a ich paradygmat składniowy (na przykładzie wybranej grupy przymiotników oceniających), w: Prace Naukowe Uniwersytetu Ślaskiego w Katowicach nr 1322, Katowice, s. 86-99.

Karolak S., 1984, Składnia wyrażeń predykatywnych, w: Z. Topolińska (red.), Gramatyka współczesnego języka polskiego. Składnia, Warszawa: PWN, s. 11-211.

Karolak S., 1999, Przyimek, w: K. Polański (red.), Encyklopedia językoznawstwa ogólnego, Wrocław: Zakład Narodowy im. Ossolińskich, s. 472-475.

KoseK I., 1995, Problem interpretacji gramatycznej niektórych trzysegmentowych ciągów słów tekstowych, Zeszyty naukowe WSP w Olsztynie I. Prace Filologiczne 1, s. 255-267.

LeIBNiz G. W., 1955, Nowe rozważania dotyczace rozumu ludzkiego, t. 1, Warszawa: PWN.

ŁAPA R., 2006, Przyimki wtórne w tekstach prawnych, Język Polski LXXXVI, s. $358-366$.

Milewska B., 2003a, Przyimki wtórne we współczesnej polszczyźnie, Gdańsk: Wydawnictwo Uniwersytetu Gdańskiego.

Milewska B., 2003b, Słownik polskich przyimków wtórnych, Gdańsk: Wydawnictwo Uniwersytetu Gdańskiego.

Nowak T., 2006, Semantyczno-składniowy opis fraz przyimkowo-nominalnych zawierających wyrażenia $w$ głębi i w obrębie, Poradnik Językowy 5, s. 23-37. 
Nowak T., 2008, Przyimki lokatywno-inkluzyjne we współczesnym języku polskim: w głębi, w obrębie, w środku, we wnętrzu, Katowice: Wydawnictwo Naukowe Uniwersytetu Śląskiego.

Przybylska R., 2002, Polisemia przyimków polskich w świetle semantyki kognitywnej, Kraków: Universitas.

Puzynina J., 2000, Uczucia a postawy we współczesnym języku polskim, w: I. Nowakowska-Kempna, A. Dąbrowska i J. Anusiewicz (red.), Język a Kultura XIV, Wrocław: Wydawnictwo Uniwersytetu Wrocławskiego, s. 9-24.

SJPD - Doroszewski W. (red.), 1958-1969, Słownik języka polskiego, Warszawa: Wiedza Powszechna, PWN.

SJPSz - Szymczak M. (red.), 1978-1981, Słownik języka polskiego, Warszawa: PWN.

SWJP - Dunaj B. (red.), 2001, Słownik współczesnego języka polskiego, Warszawa: Reader's Digest Przegląd.

SzUPRYCZYŃSKA M., 1978, Cechy składniowe formy mianownikowej przymiotnika w polskich zdaniach łącznikowych, w: Studia gramatyczne II, Wrocław, s. 63-103.

USJP - Dubisz S. (red.), 2003, Uniwersalny słownik języka polskiego, Warszawa: Wydawnictwo Naukowe PWN.

WSFJP - Müldner-Nieckowski P., 2003, Wielki słownik frazeologiczny języka polskiego, Warszawa: Świat Książki.

ŻEBEREK T., 1994, Funkcjonowanie przyimków $i$ wyrażeń przyimkowych $w$ tekście rosyjskim i polskim, Kraków: Wydawnictwo Naukowe WSP.

\section{Is the general-reference preposition ,w stosunku do" equivalent to lexical units ,w odniesieniu do" and „w porównaniu $z$ "?}

( s u m m a r y )

In the article I discuss the meaning of the general-reference preposition $w$ stosunku $d o$ 'in relation to'. After analyzing the usage of this preposition, I have established the contexts of uses of $w$ stosunku do considered as a lexical unit. I compare $w$ stosunku do with the prepositions $w$ odniesieniu do 'with reference to' and w porównaniu z 'in comparison with', recognized as synonyms of $w$ stosunku do, in order to extract the semantic features of $w$ stosunku do. As a result of the conducted analysis I claim that the discussed unit is unambiguous, and I formulate an appropriate definition of its meaning. 